Восточно-европейский журнал передових технологий. - 2014. - №5/11(71). - С. 38 - 41. DOI: 10.15587/17294061.2014.27668

Priss O. Enzymatic antioxidants in tomatoes and sweet bell pepper fruits under abiotic factors / O. Priss, V. Kalytka // Ukrainian Food Journal. - 2014. - Vol. 3, № 4. - P. 505-516

ной активности экстрактов из корней и корневиша хрена и ее стабильности к Химия. - 2006. - Т. 47, № 3. - С. 350-352.

Kopyra M. Antioxidant enzymes in paraquat and cadmium resistant cell lines of horseradish / M. Kopyra, E. A. Gwóźźz // Biological Letters. - 2003. - № 40. - P. 61-69. bwmetal.element.agro-article-b35f7e54-691c-4c38-98d1-01921 e93b8f

8. Жукевич О. Фітонцидна активність рослинної сировини / О. Жукевич // Продовольча індустрія АПК. - 2013. - № 2. - С. 21 -

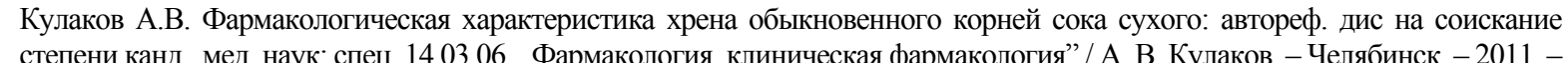
$22 \mathrm{c}$.

10. Пруднікова Т.І. Товарознавча оцінка гомогенних фітодобавок 3 хрону, виготовлених за допомогою кріогенного подрібнення: автореф. дис. на здобуття наук. ступеня канд. техн. наук: спец. 05.18.15 „Товарознавство харчових продуктів

1. Majewska A. Antioxidant properties of leaf and root extract and oil from different types of horseradish (Armoracia rusticana Gaertn.)

actions of horseradish (Armoracia rusticana) / M. R. Cirimbei, R. 3. Influence of technological processes on the phenol content and - P. P. 111-115.
. L. Tomsone, Z. Kruma, R. Galoburda [et al.] // 2nd International conference on nutrition and food sciences IPCBEE. - 2013. - Vol.
53. - . $6-10$. DOI: 10.7763/PCBEE 2013. V53.2.

4. Li X. Correlation of glucosinolate content to myrosinase activity in horseradish (Armoracia rusticana) / L. Xian Li, Mosbah M.
Kushad // J. Agric. Food Chem. - 2004 - № 52. - - 6950 . 6955. DOI: 10.1021/j0401827

15. Kosson R. Effect of long term storage on some nutritive components and isothiocyanates content in roots of two horseradish types / R
Kosson, M. Horbowicz // Vegetable crops research bulletin. - 2008. - Vol. 69. - P. 155-164. DOI: 10.2478/v10032-008-0030-3 6. Землянухин А.А. Мальй практикум по биохимии : [учебное пособие] / Александр Алексеевич Землянухин. - Воронеж

Изд-во ВГУ, 1985. - 128 c.
17. Пат. 2144674 Российская Федерация, МПКТ G 01 N33/52, G 01 N33/68. Способ определения антиоксидантной активности супероксиддисмутазы и химических соединений / Сирота Т. В.; заявитель и патентообладатель Сирота Т.В. Скалецька Л.Ф. Основи наукових дослілжень зі зберігання та по

Подпрятов, О.В. Завадська. - К.: НАУ, 2006. -202 c.

19. Прісс О.П. Вплив обробки бактерицидно-антиоксидантним препаратом Хр+Д+Л на розвиток мікроорганізмів при зберіганні помідора // О.П. Прісс, В.Ф. Жукова / Збірник наукових праць УДАУ. - Умань, 2009. - Вип. 71. - Ч. 1: Агрономія. - С. $159-166$.

адреналина / Е. . Рябинина, ЕЕ. Зотова, ЕН. Ветрова [и расти / Хйнояо сырья при исследовании процесса аутоокисле

ДКК 635.753:664.8.035.76

DOI

\section{ДИНАМІКА ЗМІНИ МАСИ ЗЕЛЕНІ ПЕТРУШКИ ПІД ЧАС}

ЗБЕРІГАННЯ

О. П. Прісс, кандидат с.-г. наук, доцент E-mail: olesyapriss@gmail.com кафедра технології переробки та зберігання продукції сільського господарства Таврійський державний агротехнологічний університет пр. Б. Хмельницкого 18, м. Мелітополь, Запорізька обл.,Україна, 72312 E-mail:alina_potapenko@ukr.net

Анотація. Досліджено динаміку зміни маси зелені петрушки під час зберігання. Встановлено пряму залежність між рівнем втрати маси, кількістю опадів і гідротермічним коефіцієнтом періоду вегетації ( $\mathrm{r}=0,82 \ldots . .099)$. Природна вищі, ніж в петрушки осіннього збору на $2,8 \%$. Помітне в'янення петрушки спостерігається при втраті нею близько $15 \%$ маси. Застосування способу зберігання з живильним середовишем на основі аграрного гілрогелю та антиоксидантів дозволяе знизити втрати маси під час зберігання зелені петрушки більш ніж в 4 рази та подовжити ермін зберігання до $60-100$ діб.

Ключові слова: зелень петрушки, зберігання, природна втрата маси, погодні фактори, антиоксиданти.

Аннотация. Исследована динамика изменения массы зелени петрушки при хранении. Установлена прямая зависимость между уровнем потери массы, количеством осадков и ГтК периода вегетации ( $\mathrm{r}=0,82 \ldots . .0,99)$. Естественная потеря массы обратно коррелирует с суммой активных температур $(\mathrm{r}=-0,76 \ldots-0,91)$. Потери массы зелен весеннего сбора выше, чем в петрушке осеннего сбора на 2,8 \%. Заметное увядание петрушки наблюдается при потер 作 хранения до $60-100$ дней.

Ключевые слова: зелень петрушки, хранение, естественная убыль массы, погодные факторы, антиоксиданты.
Вступ

Зеленні овочі - доступні та багаті біологічно активними речовинами продукти, що мають Одокий попит споживачів упродовж всього року.

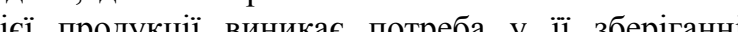
Проблемі збережения зелених овочів присвячені, пов'язано зі складністю їх зберігання Одним із нових способів зберігання зеленних овочів, який цінності є зберігання за використання аграрного гідрогелю та антиоксидантів [4].

\begin{tabular}{c} 
Постановка проблеми та їі зв'язок 3 \\
найважливішими науковими та практичними \\
завданнями \\
\hline
\end{tabular}

Однією 3 причин низької придатності до зберігання зелених овочів $\epsilon$ інтенсивне в'янення. Це пов'язано з великою листовою поверхнею, яка сприяе активному випаровуванню вологи. Після збору, листові овочі піддаються стресу на який рослини реагують збільшенням швидкості випаровування вологи [5]. Випаровування вологи плодами і овочами під час зберігання, негативно впливас на нормальне протікання процесів обміну речовин. У результаті зневоднення знижуеться тис всередині клітини 1 клітинній стінці, що текстурних змінах [6]. За рахунок випару вологи відуростий пбуток маси зеленних овочов іс. На впливают ууови вирошурания та зберігани [7-8] Тому виникас необхінність у встановтенні зв'язгу між умовами вегеташії, зберігання та природним убутком маси зелені петрушки.

\section{Огляд літератури}

Лежкість овочів визначасться сортом, погодними умовами та сиосбом зберігання [9]. бірхімінного складу в період вегетанії(ессн-осін), вмісту розчинних та нерозчинних речевин. Зменшення маси зеленними овочами піл час зберігання залежать від віку рослин та поголних умов під час вегетації [5,10].

Для більшості продукції достатньо 3 - 6 \% втрат від маси у свіжому вигляді, щоб викликати помітне погіршення якості [11]. Згідно 3 деякими велику кількість наукових прашь [1-3], ше сприяє мінімальним втратам якості та біологічної виражається в зниженні тургору, втраті кольору, витрачання органічних речовин на дихання дослідженнями, товарна якість петрушки . (2) рес-салату та м'яти відмічались після втрати . мають товарний вигляд навіть після втрати 25 ер с

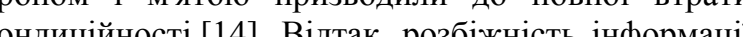

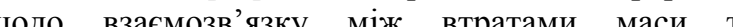
дослідження стосовно впливу природного убутку маси зелені петрушки на іii товарний вигляд післи зберігання.

Основна частина.

Метою досліджень було виявити вплив умов вирощування та зберігання на динаміку природних (3) якістю зелені петрушки.

Дослідження проводилися У $2012-2013$ рр. на
базі лабораторії технології первинної обробки і бберігання «Агротехнологій та екології» Таврійського державного агротехнологічного університету м. Мелітополя та агропідприсмствах зберігання закладали зелень перушшки осіннього веснянои зрізу сориів Оскар і Новас, що відовіда вимогам ДСТУ 6010: 2008 «Петрушка молод свіжа. Технічні умови» [15].

Дослідну зелень петрушки розфасовували у пучки по 150 г та вкладали стеблами поліетилено пакети розміром $80 \times 30$ мм, гідрогель. Для запобіганя втратам поживто речовин петрушки, у розчин тірогено композичію з антиоксидантів іонолу і хлорофіліплу в наступних конщентрашіях: іонол (I) - 0,012, 0,024 0,036; хлорофіліпт (Хл) - 0,25\% [4]. Гідрогель - ше гранули синтетичного гідрофільного полімеру, які власна маса, а потім віддають ііі рослинам в міру необхідності. Для запобігання втратам речовин пігментного комплексу у розчин гідрогелю вводили композиції з різними концентраціям сонолу (I) та хлорофіліпу (Хл). Хлорофыліп являс собою екстракт 3 листя евкаліпту який містить суміш хлорофілів а і b і володіс антисептичними та кондиційністю зеленних овочів, потребу Мелітопольського району Запорізької області. На поглинають до 250 разів більше вологи ніж іх 
\begin{tabular}{lllll} 
дезінфікуючими властивостями [16]. & Іонол - & допомогою мікроскопа XSP-146TP, фіксуванням \\
\hline & & високої & знімків камерою Kodak та аналізом на моніторі
\end{tabular} синтетичний харчовий антиоксидант високої знімків камерою Кodak та
активності [17].

Температура зберігання $1 \pm 0,5^{\circ} \mathrm{C}$, відносна - Погодні умови достовірно різняться залежно від вологість повітря $95 \pm 3 \%$. За контроль приймали сезону вирощування. За вегетаційний період зелень петрушки, котра зберігалася в холодильнику петрушки весняного збору, сума активних за тих самих умов. Природні втрати маси визначали керуючись 80,7 мм; ГТК-1,15; осіннього $-3764{ }^{\circ} \mathrm{C} ; 239,9$ мм дСТу 6010.2008 та рекомендаціями з досліджень зі та 0,91 відповідно (середне по сезонах за $2011-$ Мікронн
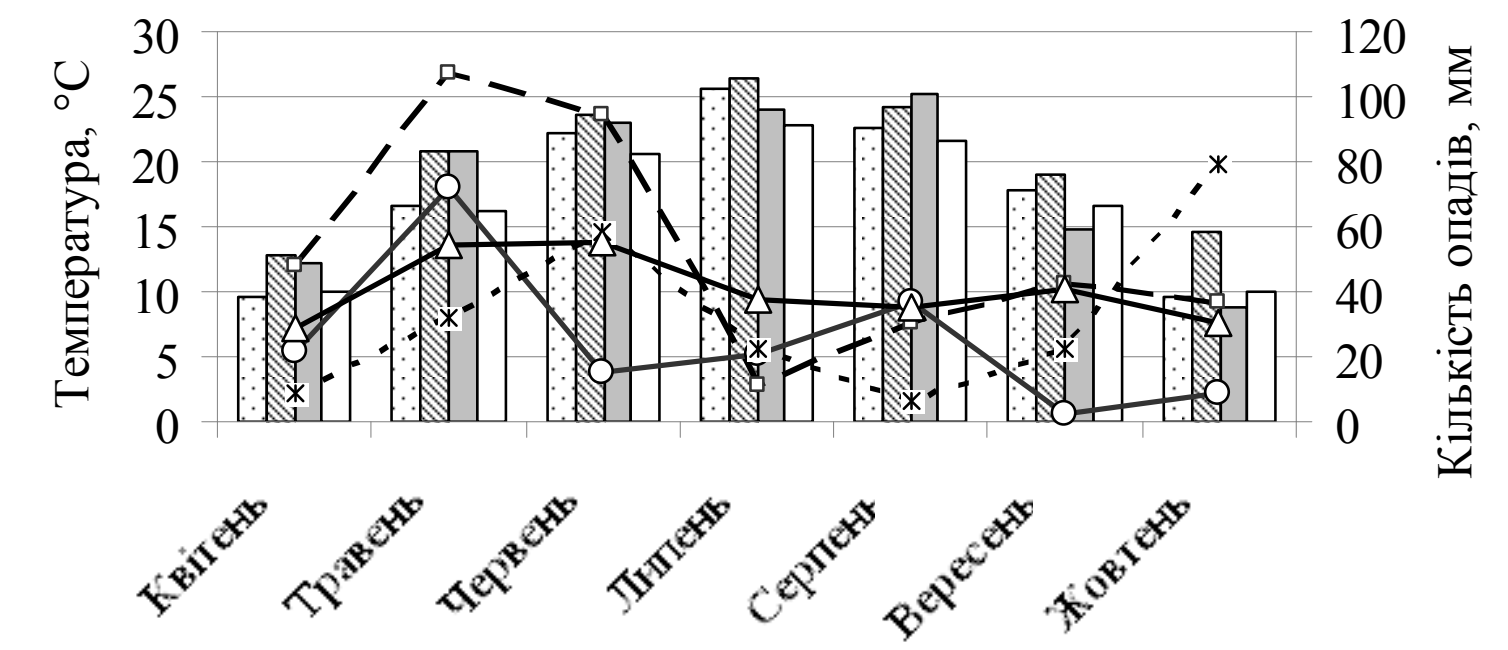

Рис. 1. Гідротермічні умови періоду вегетації зелені петрушки: середньодобова температура: $\square-2011, \square-2012, \square-2013, \square$ - середня багаторічна; опади : - - $-2011,-0-2012, \cdots * \cdots$ $2013,-\triangle-$ - середня багаторічна.

Згідно 3 результатами наших досліджень, коефіціентом (ГТК) при вирощуванні природна втрата маси листям петрушки під час $(\mathrm{r}=0,78 \ldots ., 9)$, що

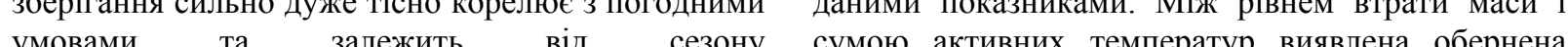
вирощування (табл. 1). кореляційна залежність $(\mathrm{r}=-0,76 \ldots-0,94)$, що вказує Встановлена пряма кореляція між рівнем втрати на позитивний вплив даного фактора на маси та кількістю опадів $\mathrm{i}$ гідротермічним збереженість зелені петрушки.

Таблиця 1 - Кореляційна залежність втрати маси листям петрушки від погодних умов, середнє в контрольних варіантах за 2011-2013 pp

\begin{tabular}{|c|c|c|c|c|}
\hline Сезон збору & Сорт & САТ & Кількість опадів & ГТК \\
\hline \multirow{2}{*}{ Весна } & Оскар & $-0,77$ & 0,99 & 0,93 \\
\cline { 2 - 5 } & Новас & $-0,76$ & 0,99 & 0,93 \\
\hline \multirow{2}{*}{ Осінь } & Оскар & $-0,94$ & 0,78 & 0,87 \\
\cline { 2 - 5 } & Новас & $-0,94$ & 0,78 & 0,87 \\
\hline
\end{tabular}

Під час зберігання контрольних партій кореляцію, а між рівнем сухих речовин та петрушки, на 40 добу зберігання зелень весняного кількістю опадів і ГТК-обернену, що свідчить про бору втратила - 20,9\% (Оскар) та 22,74\% (Новас) негативний вплив даних факторів на накопичення від початкової маси. Осіня зелень мала на $5,41 \%$ сухих речовин овочами [19].

(середне за 2012-2013 pр. по двох сортах) нижчі На кінець першої декади зберігання, втрати втрати маси (рис. 2, 3). Така різниця у втраті маси маси петрушки незалежно від сезону склали біля пяснюється вілмінностями біохімічного склалу зелені весняного збору склав трохи менше $6 \%$ внаслідок різних метеорологічних умов періоду осінньго - вдвічі менше. Третій етап зберігання вегеташії. Так, між вмістом сухих речовин та сумою - лля петрушки зібраної навесні охарактеризувався
7,3\% - Новас. Зелень осіннього збору сорту Новас осіннього збору за аналогічний проміжок часу продемонструвала подібні результати $(7,8 \%)$, склали дещо більше $2 \%$. Найвищий убуток маси оскільки цей період для неї збігався із зняттям зі відмічено в останній період зберігання, незалежно зберігання, як 1 для петрушки цього ж сорту, від сорту, сезону збору.

зібраної навесні. Втрати зелені сорту Оскар

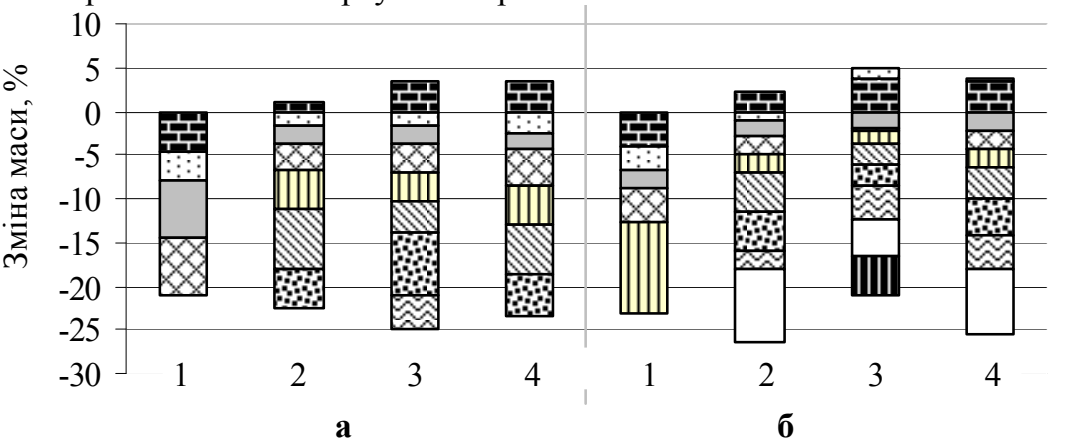

Рис. 2 Динаміка зміни маси при зберіганні зелені петрушки сорту Оскар, (середнє 2012, 2013 рp.) $1 \square$ Контроль, $2-0,012 \mathrm{I}+0,25 \mathrm{Xл}+\mathrm{A} \Gamma, 3-0,024 \mathrm{I}+0,25 \mathrm{Xл}+\mathrm{A} \Gamma, 4-0,036 \mathrm{I}+0,25 \mathrm{Xл}+\mathrm{A} \Gamma$; 보 - 0-10 діб,

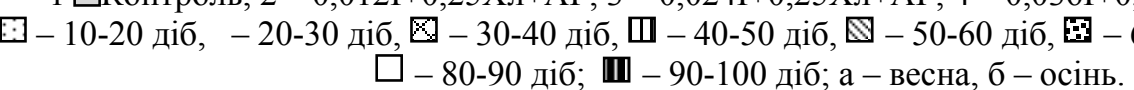

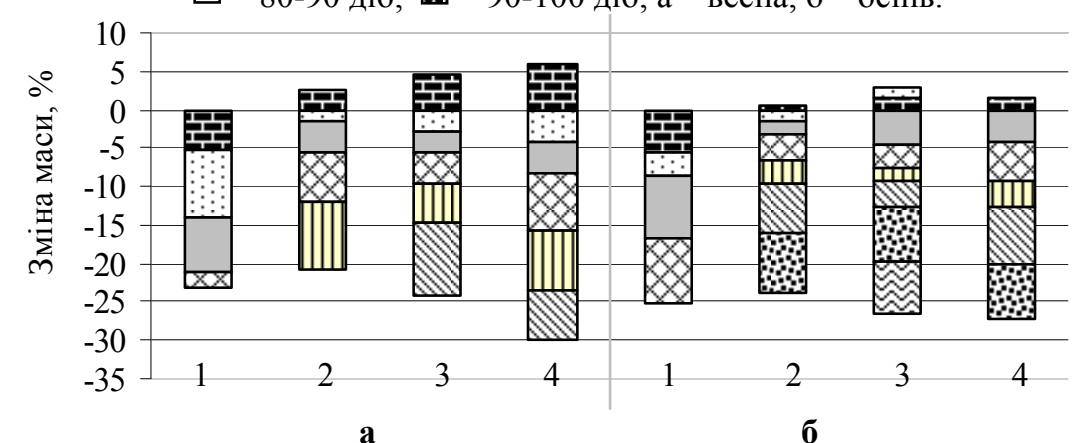

Рис. 3 Динаміка зміни маси при зберіганні зелені петрушки сорту Новас, (середнс 2012, 2013 рр.) $\square$ - Контроль, $2-0,012 \mathrm{I}+0,25 \mathrm{Xл}+\mathrm{A} \Gamma, 3-0,024 \mathrm{I}+0,25 \mathrm{X} л+\mathrm{A} \Gamma, 4-0,036 \mathrm{I}+0,25 \mathrm{Xл}+\mathrm{A} \Gamma$; $\mathbf{I}-0-12$ діб,

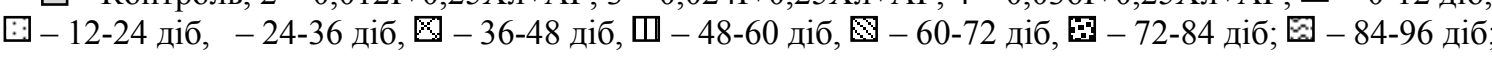

$$
\text { а }- \text { весна, } 6 \text { - осінь. }
$$

Згідно 3 нашими дослідженнями, помітне в'янення петрушки спостерігається при втраті нею близько $15 \%$ маси

Застосування способу зберігання з живильним середовищем на основі аграрного гідрогелю дозволя соло зози зелені петрушки як веснаного тас осінного сезону збору та подовжити терм зберігання до 60-100 діб Крім того, на початковому етапі зберігання спостерігасться приріст маси, шо пояснюеться абсорбуванням вологи 3 живильного середовища (рис. 2-3). В подальшому, динаміка втрати маси така ж як і в контролі, однак рівень природного убутку суттево нижчий на кожному етапі зберігання.

зберігався у живильному середовищі на основі агрогелю з концентрацією іонолу $0,024 \%$. На 40 добу втрати маси склали: 3,74\% - весняний збір, 1,78\%- осінній (середне 392013 рр. по Tare . аними аналізу ультраструктури (рис. 4).

Розмір клітин епідермальної тканини на 40 день

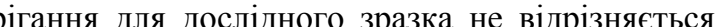
від початкового. Клітини ж петрушки контрольного варіанту істотно зменшились та деформувались. . 3,8...4,4 рази (середне по сортах) у порівнянні з стінки, що пояснюеться істотно вищим вмістом б, Найдовшу тривалість зберігання та найменший контрольному, що свідчить про високий тургор

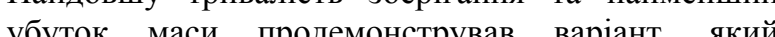
стінок клітин. 


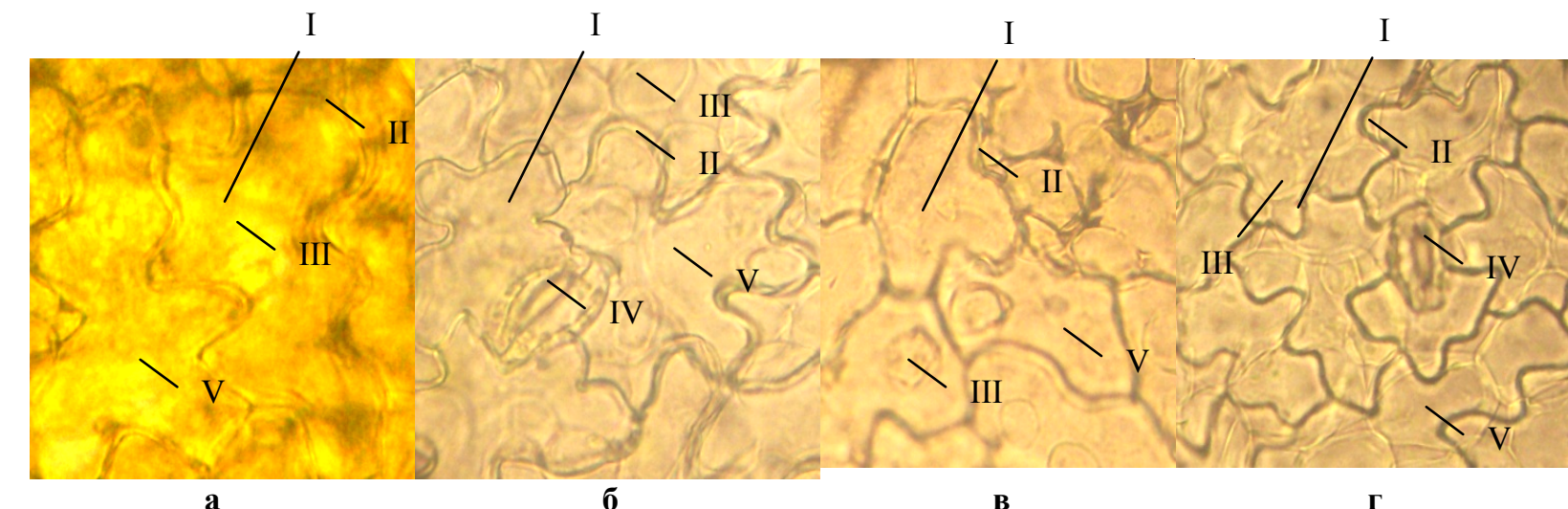

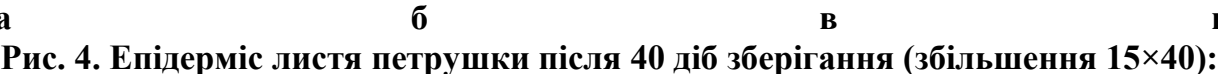

а - верхньої сторони, дослід; б - нижньої сторони, дослід; в - верхньої сторони, контроль; г - нижньої сторони, контроль; I - клітина, II - клітинна стінка, III - хлоропласти, IV - продихи, $\mathbf{V}$ - цитоплазма.

Отримані дані дозволяють рекомендувати даного фактора на збереженість зелені петрушки. спосіб зберігання на основі аграрного гідрогелю та Втрати маси зелені зібраної навесні за період антиоксидантів для зберігання зелені петрушки з зберігання на 2,8\% перевищували убуток маси

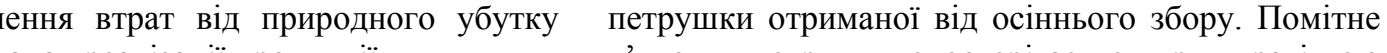
маси на усіх етапах реалізанії продукції

\section{Висновки.}

Між рівнем втрати маси та кількістю опадів ГТК при вирощуванні існує сильний прями зв'язок $(\mathrm{r}=0,82 \ldots 0,99)$. Природна втрата мас обернено корелюс з сумою активних температур петрушки отриманої від осіннього збору. Помітне
в'янення петрушки спостерігається при втраті нею близько $15 \%$ маси. Застосування споособу

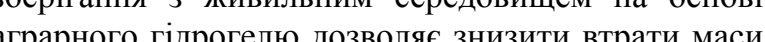
піл час зберігання зелені петрушки більш ніж в 4 рази (40 доба) та подовжити термін зберігання до $60-100$ діб.
Journal of Food, Agriculture \& Environment. - 2007. - Vol.5 (2). P. 31-34

. Hruschka H.W. Storage and shelf-life of packaged watercress, parsley and mint / H.W. Hruschka, C.Y. Wang // USD Mkt. Res. Rep. - 1979. - No 1102. -19 pp.

14. Cantwell M. Postharvest physiology and handling of fresh culinary herbs / M. Cantwell, M.S. Reid // J. Herbs, Spices an

рушка молода саз 16. Дикий І. Л. Мікробіологічне обгрунтування придатності хлорофіліпту для створення м'якої лікарської форми антиінфекцийного призначення / І. Л. Дикий, В. М. Остапенко, Н. І. Філімонова [та ін.] // Вісник фармації. - 2005.

17. Санітарні правила і норми по застосуванню харчових добавок [Електронний ресурс] : Затв. МОЗ України 23.07.96

Л.Ф. Скалецька, Г.І. Подпрятов, О.В. Завадська. - К. : «ЦП «Компринт», 2013. - 242

\section{УДК 664.8.03:634.11}

ОКИСНИЙ СТРЕС І АНТИОКСИДАНТНА СИСТЕМА ЗАХИСТУ

\section{ПЛОДІВ ЯБЛУН}

М.С.Сердюк, кандидат сільськогосподарських наук, доцент * E-mail: igorserduk@mail.ru

С.С.Байбєрова, кандидат сільськогосподарських наук, *кафедра технології переробки та зберігання продукції сільського господарств

пр. Б.Хмельницьккого, 18, м. Мелітополь, Запорізька обл., 72312

Анотація. Дослідження присвячено вивченню закономірностей функціонування антиоксидантної захисноі системи і встановленню визначального чинника у розвитку стрес-толерантності плодів яблуні. Об'єктами досліджень
обрано плоди яблуні чотирьох сортів: Айдаред, ГолденДелішес, Ренет Симиренка, Флоріна. Встановлено, що під дієюе обрано плоди яблуні чотирьох сортів: Айдаред, Голденделішес, Ренет Симиренка, Флоріна. Встановлено, що під дієе стресових погодних чинників у плодах яблуні розвиваєьься окисний стрес, про що свідчить значне зростання вмісту

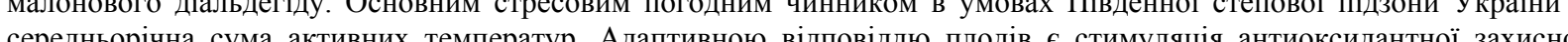
системи, яка проявлясться в підвищенні ендогенного рівня фенольних речовин, цукрів i активност супероксиддисмутази і пероксидази. Розраховані вектори пріоритетів свідчать, що при окисному стресі домінуюч роль у захисний відповіді плодів яблуні сортів Ренет Симиренка та Голден Делішес належить фенольним речовинам. яблуках сортів Флоріна i Айдаред визначальною $є$ дія антиоксидантних ферментів супероксиддисмутази перокдази.

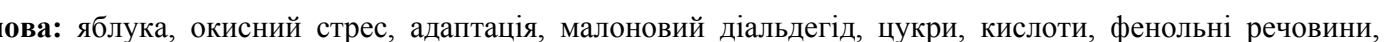
аскорбінова кислота, супероксидлисмутаза, пероксидаза.

Аннотация. Исследования посвящены изучению закономерностей функционирования антиоксидантной защитной системы и выявлению определяющего фактора в развитии стресс-толерантности плодов яблони. Объектами исследований были выбраны плоды яблони четырех сортов. Айдаред, Голденделишес, Ренег Симиренко, Флорин установлено, что под действием стрессовых погодных факторов в плодах яблони развивается окислительный стресс, фактором в условиях Южной степной зоны Украины является среднегодовая сумма активных температур Адаптивной ответом плодов является стимуляция антиоксидантной защитной системы, которая проявляется повышении эндогенного уровня фенольных веществ, сахаров и активности супероксиддисмутазы и пероксидазы.

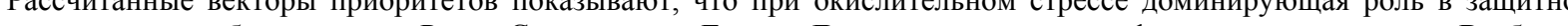

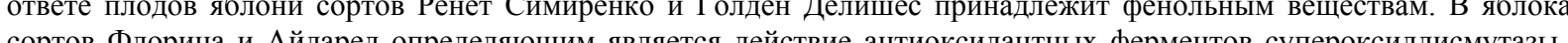

Ключевые слова: яблоки, окислительный стресс, адаптация, малоновый диальдегид, сахара, кислоты, фенольные вещества, аскорбиновая кислота, супероксиддисмутаза, пероксидаза.

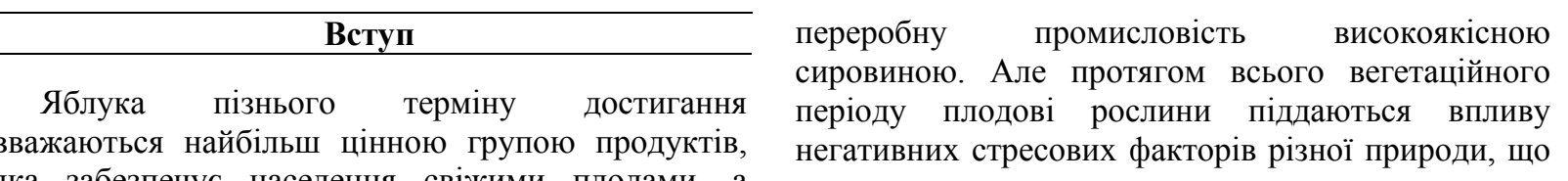

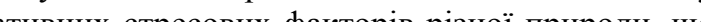
яка забезпечує населення свіжими плодами, а 